Article

\title{
Vegetation Carbon Storage, Spatial Patterns and Response to Altitude in Lancang River Basin, Southwest China
}

\author{
Long Chen ${ }^{1}$, Changshun Zhang ${ }^{2, *}$, Gaodi Xie ${ }^{2}$, Chunlan Liu ${ }^{1}$, Haihua Wang ${ }^{1}$, Zheng Li ${ }^{1}$, \\ Sha Pei ${ }^{1}$ and Qing Qiao ${ }^{1}$
}

1 Beijing Municipal Research Institute of Environmental Protection, National Engineering Research Center for Urban Environmental Pollution Control, Beijing 100037, China; bryum@163.com (L.C.); liuchunlan@cee.cn (C.L.); wanghaihua@cee.cn (H.W.); lizheng@cee.cn (Z.L.); peisha_259@163.com (S.P.); qiao1979@126.com (Q.Q.)

2 Institute of Geographic Sciences and Natural Resources Research, Chinese Academy of Sciences, Beijing 100101, China; xiegd@igsnrr.ac.cn

* Correspondence: zhangcs@igsnrr.ac.cn; Tel.: +86-10-6488-8118; Fax: +86-10-6485-4230

Academic Editor: Marc A. Rosen

Received: 17 September 2015; Accepted: 21 January 2016; Published: 25 January 2016

\begin{abstract}
Vegetation plays a very important role of carbon (C) sinks in the global C cycle. With its complex terrain and diverse vegetation types, the Lancang River Basin (LRB) of southwest China has huge $C$ storage capacity. Therefore, understanding the spatial variations and controlling mechanisms of vegetation $C$ storage is important to understand the regional $C$ cycle. In this study, data from a forest inventory and field plots were used to estimate and map vegetation $C$ storage distribution in the LRB, to qualify the quantitative relationships between vegetation $C$ density and altitude at sublot and township scale, and a linear model or polynomial model was used to identify the relationship between $C$ density and altitude at two spatial scales and two statistical scales. The results showed that a total of $300.32 \mathrm{Tg} C$ was stored in the LRB, an important $C$ sink in China. The majority of $C$ storage was contributed by forests, notably oaks. The vegetation $C$ storage exhibited nonlinear variation with latitudinal gradients. Altitude had tremendous influences on spatial patterns of vegetation $C$ storage of three geomorphological types in the LRB. C storage decreased with increasing altitude at both town and sublot scales in the flat river valley (FRV) region and the mid-low mountains gorge (MMG) region, and first increased then decreased in the alpine gorge (AG) region. This revealed that, in southwest China, altitude changes the latitudinal patterns of vegetation $C$ storage; especially in the AG area, C density in the mid-altitude $(3100 \mathrm{~m})$ area was higher than that of adjacent areas.
\end{abstract}

Keywords: carbon storage; latitude; altitude; slope; Lancang River Basin

\section{Introduction}

The carbon (C) cycle is the Earth's largest material and energy cycle, in which carbon dioxide $\left(\mathrm{CO}_{2}\right)$ in the atmosphere is turned to organic matter through vegetation and used as the most basic material and energy source for human life and production [1]. Amid the growing concerns about global warming due to increasing greenhouse gases (GHGs) like $\mathrm{CO}_{2}$ since the industrial revolution, the $C$ storage of terrestrial ecosystems, a key $C$ sink, has an important role in the global C cycle [2-5].

Globally, a total forest $\mathrm{C}$ sink amount of about 4.0 Pg $\left(1 \mathrm{Pg}=10^{15} \mathrm{~g}\right)$ was estimated based on forest inventory data and long-term ecosystem information from 1990 to 2007, and globally, forests can sequester half of the fossil-fuel derived $\mathrm{CO}_{2}$ emissions [5]. China's forests had a biomass $\mathrm{C}$ sink of $1896 \mathrm{Tg}\left(1 \mathrm{Tg}=10^{12} \mathrm{~g}\right)$ during 1977-2008, with an annual C sink of $70.2 \mathrm{Tg} /$ year [6]. However, due to low stand age and a lack of forest management, mean $\mathrm{C}$ density in China was quite low compared to 
the world average. On the other hand, with large forest area and the implementation of sustainable forest management, China's forests have great potential for $C$ sequestration in the future. From 2005 to 2050, an annual C sink of $70.2 \mathrm{Tg} /$ year was predicted by Hu et al. [7]. Therefore, C storage by vegetation is an effective way to address global climate change, and it has become a basic consensus of the international community and a cutting-edge hotspot of research on ecology, attracting special attention from scientists and governments [8,9].

Spatial patterns of forest $C$ storage at different scales have received considerable attention [10-14]. Terrain factors including slope and altitude have significant effects on $C$ storage distribution $[15,16]$. Investigations on the changes of vegetation $C$ storage with altitudinal gradients provide important data for local forest management $[17,18]$.

In China, more than one-half of forest $C$ storage was in the southwest and northeast areas, while the highest average $C$ density was observed in the southwest [19]. Influenced by the uplift of Qinghai-Tibetan Plateau, the latitudinal distribution of vegetation $C$ storage is changed by complex terrain in the Lancang River Basin (LRB), especially altitude, which affects the spatial patterns of $C$ storage significantly. Therefore, it is an ideal region to study the spatial patterns and influencing mechanisms along that altitude. The main objectives of this study were to: (1) estimate vegetation $C$ storage and explore its latitudinal pattern along the LRB; (2) analyze the allocation and variance of $C$ storage in different vegetation types and dominant trees; (3) reveal the influencing mechanisms of C storage with regard to altitude at multiple scales.

\section{Study Area}

The LRB is part of the Pacific River System and originates in the north foot of the Tanggula Mountains in central Qinghai-Tibetan Plateau (Figure 1). The Lancang River flows through Qinghai, Tibet and Yunnan from north to south before exiting from boundary at Xishuangbanna and is thereafter referred to as the Mekong River. In the Chinese territory, the area of the LRB is $16,480,000$ ha [20,21].

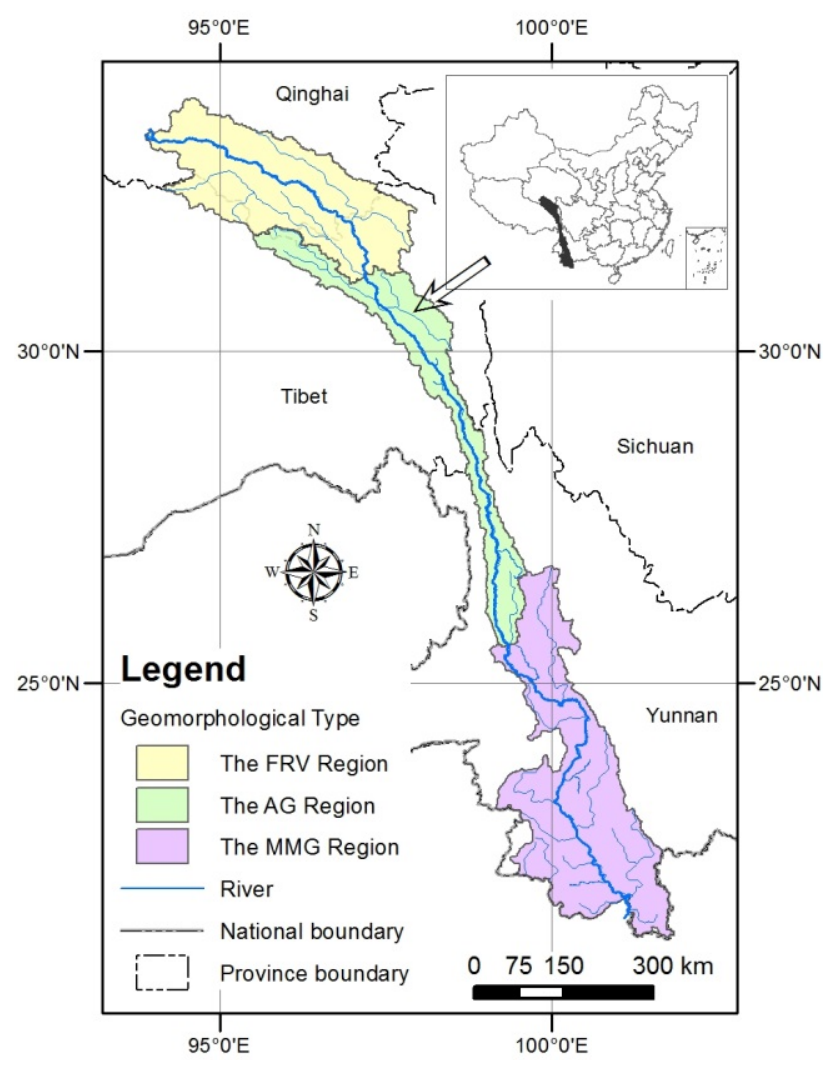

Figure 1. Location of Lancang River Basin. 
Across 13 degrees of latitude from north to south, the LRB is characterized by complex terrain, great altitudinal range and various types of climate, and containing almost all types of climate [22]. According to geomorphological types, the LRB can be divided into the flat river valley (FRV) region, the alpine gorge (AG) region and the mid-low mountain gorge (MMG) region. Above $4000 \mathrm{~m}$, the FRV region is located in river source regions, and characterized by gentle mountains and a flat shallow valley. The AG region is located in the core area of the Hengduan Mountains, characterized by a deep river valley and steep mountains, and thus forms the typical north-south "V" valley. The MMG region is located in a downstream area, and the river valley is still characterized by a " $\mathrm{V}$ " river valley, with gentle slope [22,23].

\section{Methods}

\subsection{Data Collection}

In this study, 500 plots of forest $C$ storage, which were investigated over the past few decades in southwest China, were collected to determine the model parameters. Among them, 490 plots were collected from DSIESS (Data Sharing Infrastructure of Earth System Science), which were compiled by Luo [24], and 10 from published literature [25]. Specifically, the location, vegetation type, dominant tree species, stand volume and biomass were recorded.

Forest area were obtained from the local Forest Resource Inventory database (2004-2008), investigated based on sublot every five years. Specifically, the spatial distribution, location, area, altitude, forest types, tree species, number of trees, diameter, height, age, stand volume and so on were recorded.

Shrubs of 50 plots were harvested for biomass determination from 2009 to 2012. Grassland types and their distribution areas, including 129 types in 11 categories, were derived from the Grassland Resources Map of China in 2000 (1:1,000,000), and the grass production of each grassland type was extracted from China Grassland Resource Data [26]. Other vegetation types and their areas were derived from the Vegetation Map of China in 2000 (1:1,000,000).

\subsection{Estimation of Vegetation C Storage}

Because the vegetation types were very diverse, in this paper, we estimated biomass of forest, grassland, desert and swamp, respectively. A coefficient of 0.45 was used to convert biomass to C storage [27].

Forests included arbor forests, shrubs, economic forests and bamboo. Arbor forest biomass was determined using a volume-derived approach because the data from the forest inventory only provided information on stand volume. Therefore, a biomass expansion factor (BEF) was used to convert stand volume to total biomass $[28,29]$, which has been widely used at different scales $[13,16,30,31]$. The formulas are written as follows:

$$
\begin{gathered}
B E F=\mathrm{a}+\frac{b}{V} \\
B=\sum B E F_{i} \times V_{i} \times A_{i}=\mathrm{a} \sum V_{i} \times A_{i}+b A
\end{gathered}
$$

In Formula (1), BEF represents conversion factor and $V$ represents stand volume; $\mathrm{a}$ and $\mathrm{b}$ are constants. In Formula (2), B represents biomass; BEFi, $V i$ and $A i$ represent biomass conversion factor, average stand volume and planting area of tree species $i$ respectively; $A$ represents area of town or sublot. The principle and calculating process are detailed by Fang et al. [32]

According to the Formula (1), we developed new conversion parameters ( $a$ and $b$ ) between stand volume and biomass based on 500 plots investigated in southwest China (Table 1). Parameters for some species, due to data availability, were cited from Fang et al. [33]. Regional arbor forest biomass was estimated based on Formula (2). 
Table 1. Conversion parameters between stand volume and biomass for arbor forests in southwest China.

\begin{tabular}{lcccc}
\hline \multicolumn{1}{c}{ Forest Type } & $\mathbf{a}$ & $\mathbf{b}$ & $\boldsymbol{n}$ & $\boldsymbol{R}$ \\
\hline Abies and Picea & 0.3809 & 62.8917 & 122 & 0.9123 \\
Cypress & 0.5137 & 31.0518 & 12 & 0.9855 \\
Evergreen and deciduous broadleaf mixed forest & 0.6011 & 97.3843 & 9 & 0.8287 \\
Pinus armandii, P. densata & 0.4758 & 26.6772 & 31 & 0.9594 \\
Larix & 0.6433 & 6.8686 & 22 & 0.9619 \\
P. massoniana & 0.6404 & 7.3645 & 14 & 0.9995 \\
Tropical rain forest, monsoon forest & 1.1243 & 18.5632 & 12 & 0.9946 \\
Mountainous poplar-birth forest & 0.5671 & 48.0016 & 21 & 0.8641 \\
Cunninghamia lanceolata & 0.4634 & 30.3323 & 36 & 0.8344 \\
Subtropical evergreen broadleaf forest & 0.8879 & 29.0708 & 158 & 0.9366 \\
Evergreen sclerophyllous broadleaf oaks & 0.5363 & 84.7126 & 9 & 0.9254 \\
P. Yunnanensis, P. kesiya var. langbianensis & 0.7685 & 1.5945 & 44 & 0.9955 \\
Alnus & 1.0054 & 4.4856 & 10 & 0.9994 \\
* Betula & 1.0687 & 10.2370 & 9 & 0.9770 \\
* Eucalyptus & 0.8873 & 4.5539 & 20 & 1.0000 \\
* Lucidophyllous forests & 1.0357 & 8.0591 & 17 & 0.9100 \\
* Tsuga, Cryptomeria & 0.4158 & 41.3318 & 21 & 0.9400 \\
* Populus & 0.4754 & 30.6034 & 10 & 0.9290 \\
\hline
\end{tabular}

Note: ${ }^{*}$ means that parameters are cited from Fang et al. [33]; a and b means that parameters are obtained through Formula (1); $n$ and $R$ stand for the number of samples and the correlation coefficient respectively.

Shrub biomass was estimated at an average of $28.312 \mathrm{t} / \mathrm{ha}$, which was calculated from 50 samples investigated in research area. Economic forest was estimated at an average of $23.7 \mathrm{t} / \mathrm{ha}$ [33], while some special economic forests cultivated at a large scale were estimated separately. Rubber forest biomass was calculated using the model: $y=-0.136 \cdot x^{2}+13.12 \cdot x-65.86\left(R^{2}=0.983, p<0.001\right)$, where $\mathrm{y}$ represents biomass per rubber tree and $x$ is forest age [34]. An average of $22.7 \mathrm{t} / \mathrm{ha}$ was taken for tea plant [35], and $0.0225 \mathrm{t} /$ strain for bamboo [36]. Grassland aboveground biomass was estimated by grass yield deducted by water content, which accounts for 15\% [33]. Belowground biomass was estimated using shoot/root ratios from published literature [37]. Crop biomass was ignored due to the short harvest time and fast rotation [38]; desert biomass was estimated at $0.2 \mathrm{t} / \mathrm{ha}$ and swamp biomass at $40 \mathrm{t} / \mathrm{ha}$ [33].

\subsection{Data Analysis}

To explore their spatial pattern with latitudinal gradients, vegetation $C$ storage and density were estimated using Formula (2) at township scale. Also, we drafted the scatter diagram between vegetation $C$ density and latitude at town scale and $1^{\circ}$ latitudinal scale.

To a large degree, regional $C$ storage was determined by local vegetation types and formation. We estimated $C$ storage and density of all vegetation types and dominant tree species using Formula (1).

Vegetation $C$ storage was affected by terrain with varying degrees in different geomorphological types, and we focused on the altitude factor in this study. Firstly, the differences in C density of vegetation, altitude and altitudinal range among three geomorphological regions were tested using one-way analysis of variance (ANOVA) with Duncan tests. Furthermore, a linear model or polynomial model was used to identify the relationship between $C$ density and altitude in three geomorphological regions at two spatial scales and two statistical scales (plot and $100 \mathrm{~m}$ altitudinal scale), respectively. At township scale, vegetation C density was analyzed for all towns in the LRB. At sublot scale, forest $\mathrm{C}$ density was analyzed by sublots of typical regions in three geomorphological types. Yushu Prefecture (258 sublots), Diqing Prefecture (4698 sublots) and Xishuangbanna Prefecture (1024 sublots) represent the FRV region, the AG region and the FRV region, respectively. The $C$ density of sublots was estimated using Formula (2). 
Spatial analysis and maps were produced using the ArcMap software (version 10.1). Statistical analyses and graphs were conducted using the SPSS software (version 17.0) and Origin software (version 8.5).

\section{Results}

\subsection{Spatial Distribution and Latitudinal Patterns of Vegetation C Storage along the LRB}

A total vegetation C storage of $300.32 \mathrm{Tg}$ was estimated in the LRB, including 326 towns, and the $\mathrm{C}$ density ranges from $0.09 \mathrm{Mg} / \mathrm{ha}$ to $90.40 \mathrm{Mg} / \mathrm{ha}\left(1 \mathrm{Mg}=10^{6} \mathrm{~g}\right)$, with an average of $18.89 \mathrm{Mg} / \mathrm{ha}$ (Appendix A, Figure 2). According to published literature [26,37,39], China's terrestrial vegetation C storage ranges from $4.77 \mathrm{Pg}$ to $6.42 \mathrm{Pg}, 4.68 \%-6.29 \%$ of which is stored in the LRB, though the land area takes up only $1.67 \%$ of the national total.

Vegetation $C$ storage showed nonlinear variation with latitudinal gradients, which had two maximum value at $\mathrm{N}^{\circ} 1^{\circ}$ (Xishuangbanna) and $\mathrm{N} 27^{\circ}$ (Diqing) (Figures 2 and 3). In three geomorphological regions (Figure 3), the FRV region was located in the upstream area of the LRB, characterized by high latitude and high altitude. The vegetation was dominated by grassland, resulting in low $\mathrm{C}$ density, usually below $10 \mathrm{Mg} / \mathrm{ha}$. The AG region was located in Hengduan Mountains, characterized with complex terrain and large altitudinal range, resulting in huge difference of $C$ density at same latitude. As it was also dominated by Abies and Picea, vegetation C density of Diqing Prefecture was more than $50 \mathrm{Mg} / \mathrm{ha}$. The MMG region was located in the downstream area of the LRB, and vegetation $C$ density decreased with the increasing latitude. With an average of $54.16 \mathrm{Mg} / \mathrm{ha}$, the vegetation $C$ density of Xishuangbanna Prefecture was nearly three times that of the LRB. Particularly, the average $\mathrm{C}$ density of some towns could even reach $90.40 \mathrm{Mg} / \mathrm{ha}$.

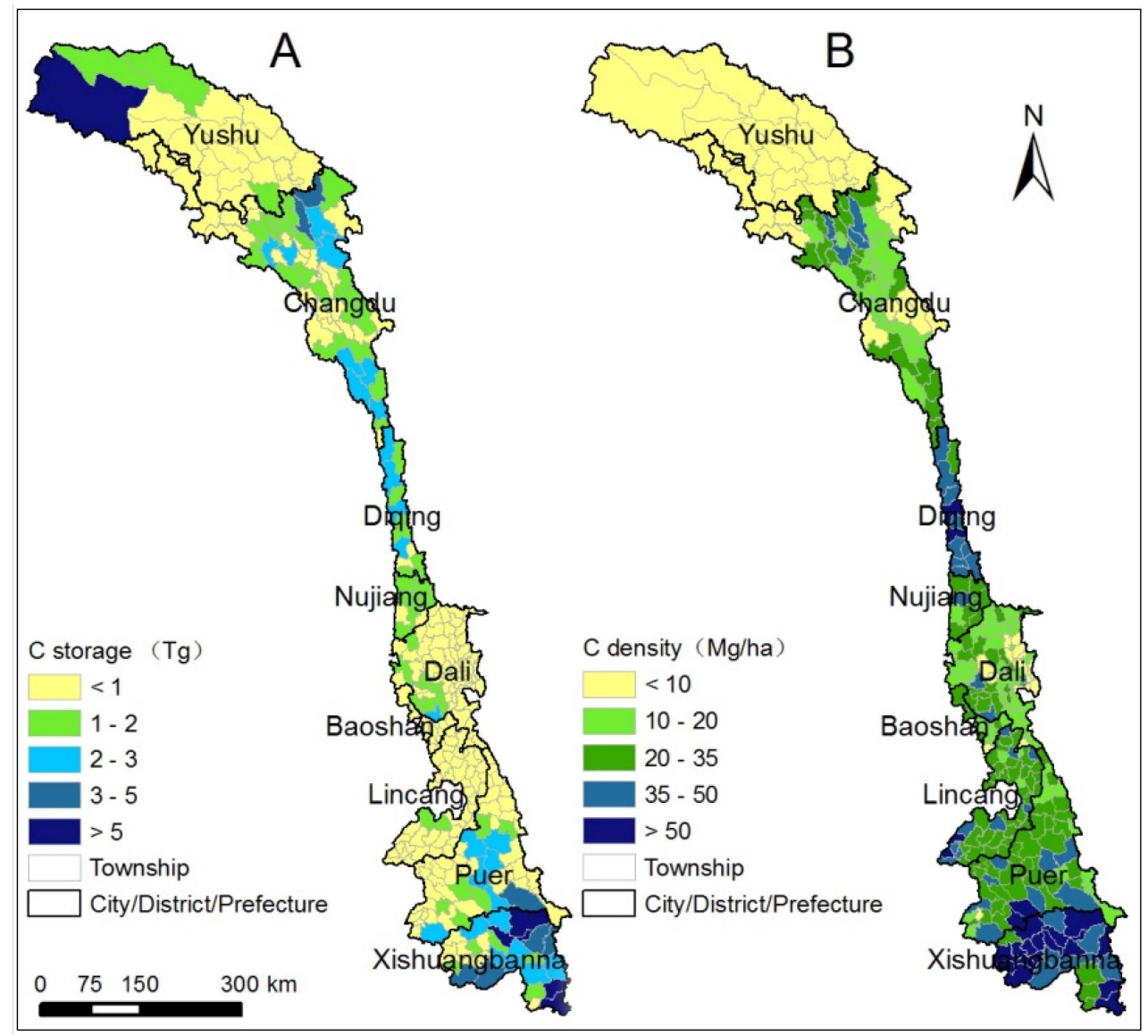

Figure 2. Spatial distributions of $C$ storage and density along the LRB. 


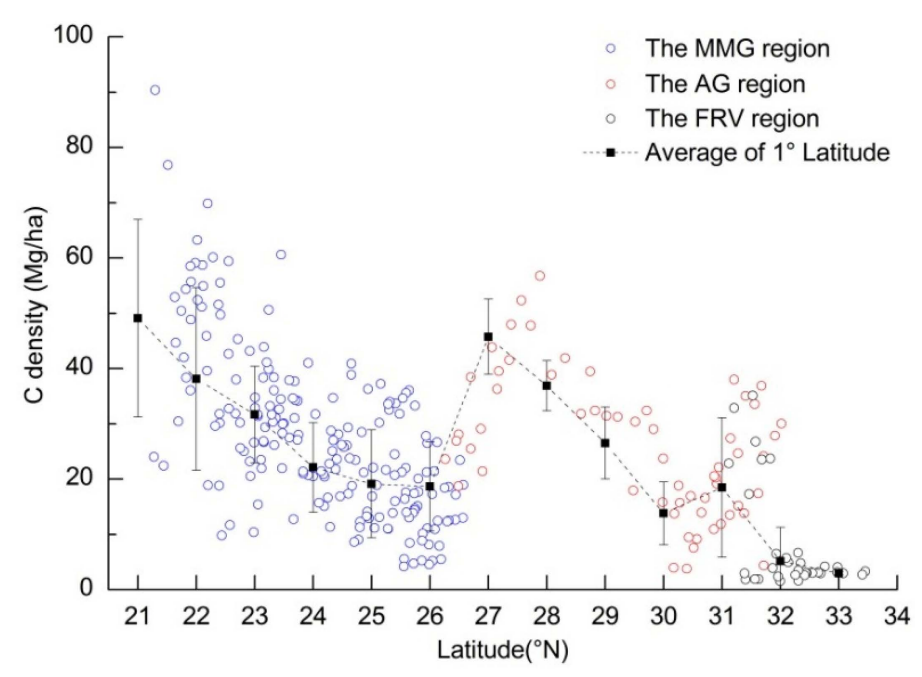

Figure 3. Latitudinal patterns of vegetation $\mathrm{C}$ density along the LRB (one plot represents one town). The blank, red and blue colors represent the FRV, AG and MMG regions, respectively.

\subsection{Storage of Vegetation Types and Dominant Tree Species}

Forests were the most important $C$ pool with $276.27 \mathrm{Tg} C$, accounting for $92.13 \%$ of the total vegetation $C$ storage (Table 2). The average $C$ density was $37.09 \mathrm{Mg} / \mathrm{ha}$. Arbor forests contributed the greatest $C$ storage, which was 10,22 , and 75 times that of shrubs, economic forests, and bamboo forests, respectively. Bamboo forests had the highest $\mathrm{C}$ density of $64.57 \mathrm{Mg} / \mathrm{ha}$, higher than the national average (32.96 Mg/ha), but lower than that of Yunnan Province (90.31 Mg/ha) [33]. In comparison with the results at the same latitude, the figure was higher than Makino bamboo ( $49.8 \mathrm{Mg} / \mathrm{ha}$ ) and Moso bamboo (40.6Mg/ha) [40]. The C density of arbor forests reached $47.95 \mathrm{Mg} / \mathrm{ha}$, higher than the national average (41 Mg/ha) [29]. Grassland, storing $21.10 \mathrm{Tg}$ C, played a significant role, accounting for $7.04 \%$ of the total vegetation $C$ storage. The average $C$ density was $2.92 \mathrm{Mg} / \mathrm{ha}$, lower than the national average (3.46 Mg/ha) [29].

Table 2. C storage and density of vegetation types.

\begin{tabular}{cccc}
\hline \multicolumn{2}{c}{ Vegetation Type } & C Storage Tg & C Density Mg/ha \\
\hline \multirow{4}{*}{ Forest } & Arbor & 238.64 & 47.95 \\
& Shrub & 23.81 & 12.97 \\
& Economic forest & 10.64 & 19.86 \\
& Bamboo & 3.17 & 64.57 \\
Subtotal & 276.27 & 37.09 \\
\hline Grassland & 21.10 & 2.92 \\
Desert & 0.09 & 0.09 \\
Swamp & 2.40 & 18.00 \\
\hline
\end{tabular}

Oaks forests were widely distributed in the LBR and hold the highest $C$ density ( $63.26 \mathrm{Mg} / \mathrm{ha}$ ), followed by Abies (62.37 Mg/ha) and Picea (60.52 Mg/ha) (Table 3). The C density of Eucalyptus was only $4.47 \mathrm{Mg} / \mathrm{ha}$, far lower than the level of other species, which could result from great cultivation in the downstream area in recent years, and the dominance of man-made young forests. In general, the $\mathrm{C}$ density of coniferous forest was higher than broadleaf forest.

Regarding dominant tree species in different regions (Table 3), few forests, mainly Sabina tibetica, were distributed in the FRV region, with an average forest $C$ density of about $20 \mathrm{Mg} / \mathrm{ha}$. The AG region, particularly in Diqing Prefecture, was dominated by dark coniferous forests, mainly Abies, Picea and alpine oak, with an average forest $C$ density above $60 \mathrm{Mg} /$ ha. Characterized by rich biodiversity, 
the MMG region, especially in Xishuangbanna Prefecture, contained a large amount of tropical seasonal rainforest, tropical montane rainforest, monsoon forest and subtropical evergreen broadleaf forest, and has huge $\mathrm{C}$ storage.

Table 3. C storage, density and distribution of dominant tree species.

\begin{tabular}{|c|c|c|c|c|c|c|c|}
\hline Tree Species & $\begin{array}{l}\text { C Storage } \\
\mathrm{Tg}\end{array}$ & $\begin{array}{l}\text { C Density } \\
{\mathrm{Mg} / \mathrm{hm}^{2}}^{2}\end{array}$ & $\begin{array}{l}\text { Distribution } \\
\text { Region }\end{array}$ & Tree Species & $\begin{array}{c}\text { C Storage } \\
\mathrm{Tg}\end{array}$ & $\begin{array}{l}\text { C Density } \\
{\mathrm{Mg} / \mathrm{hm}^{2}}^{2}\end{array}$ & $\begin{array}{l}\text { Distribution } \\
\text { Region }\end{array}$ \\
\hline Larix & 0.16 & 42.97 & AG & Betula & 0.66 & 33.41 & $\mathrm{AG}, \mathrm{MMG}$ \\
\hline P. densata & 0.40 & 33.32 & AG & Eucalyptus & 0.25 & 4.47 & MMG \\
\hline Abies & 6.92 & 60.52 & AG & Populus & 0.15 & 31.56 & AG, MMG \\
\hline Picea & 2.09 & 62.37 & AG & Castanopsis & 0.79 & 35.49 & MMG \\
\hline P. armandii & 0.61 & 30.61 & AG, MMG & Alnus & 1.80 & 31.57 & AG, MMG \\
\hline Cypress & 0.17 & 21.21 & AG, MMG & Schima & 0.16 & 26.85 & MMG \\
\hline C. lanceolata & 0.17 & 22.40 & MMG & Cassia siamea & 0.02 & 25.67 & MMG \\
\hline Tsuga & 0.59 & 50.83 & $\mathrm{AG}, \mathrm{MMG}$ & $\begin{array}{l}\text { Anthocephalus } \\
\text { chinensis }\end{array}$ & 0.02 & 21.48 & MMG \\
\hline P. Yunnanensis & 7.82 & 26.60 & MMG & Tectona grandis & 0.03 & 37.57 & MMG \\
\hline $\begin{array}{l}\text { P. kesiya var. } \\
\text { langbianensis }\end{array}$ & 23.95 & 31.32 & MMG & Hevea & 9.34 & 22.57 & MMG \\
\hline Oaks & 55.23 & 63.26 & $\begin{array}{l}\text { FRV, AG, } \\
\text { MMG }\end{array}$ & Sabina tibetica & 0.18 & 20.97 & FRV \\
\hline
\end{tabular}

\subsection{Altitudinal Patterns of C Storage in Three Geomorphological Regions}

There was no significant difference in $C$ density between the AG region and the MMG region, both being higher than that of the FRV region (Figure 4A). Altitudes of the three regions were statistically different (Figure $4 \mathrm{~B}$ ), and the altitudinal range of the AG region was significant larger than the other two regions (Figure 4C).
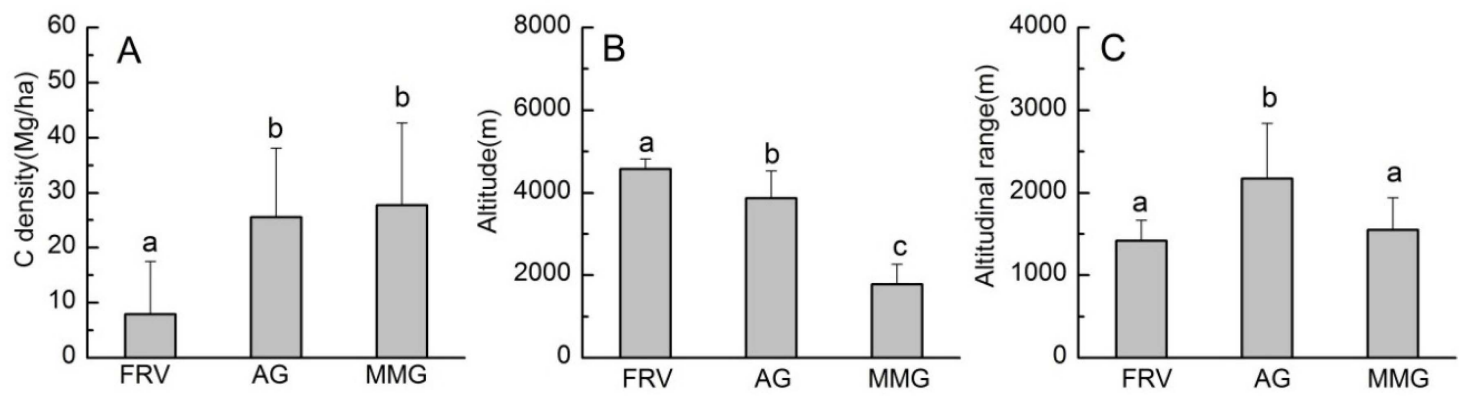

Figure 4. C density, altitude and altitudinal range of different geomorphological regions. Panels (A-C) represent $C$ storage, altitude and altitudinal range, respectively. Data were averaged and the error bar represents standard error. Data with the same small letter in each panel indicates no significant difference at the $p=0.05$ level (Duncan test).

At town scale, vegetation $C$ density decreased weakly with increased altitude in the FRV region. Altitude could explain $21 \%$ of the variation in vegetation C density at plot scale (Figure 5A), and up to $30 \%$ at $100 \mathrm{~m}$ altitudinal scale (Figure 5B). Vegetation C density first increased and then decreased with increased altitude in the AG region, peaking at $3100 \mathrm{~m}$ and exhibiting an inverted $\mathrm{U}$ shape curve. Using the polynomial model, altitude could explain $46 \%$ of the variation in vegetation $C$ density at plot scale (Figure 5A), and up to $65 \%$ at $100 \mathrm{~m}$ altitudinal scale (Figure 5B). In the MMG region, there was a significant negative linear correlation between vegetation $C$ density and altitude, which could explain $33 \%$ of the variation in vegetation C density at plot scale (Figure $5 \mathrm{~A}$ ), and up to $30 \%$ at $100 \mathrm{~m}$ altitudinal scale (Figure 5B).

At sublot scale, forest $C$ density, with small variation range, exhibited a similar altitudinal pattern to town scale, and tended toward $20 \mathrm{Mg} / \mathrm{ha}$ (Figure $6 \mathrm{~A}$,a). Forest $\mathrm{C}$ density exhibited a significant 
inverted U-shape curve for altitude both at plot scale and $100 \mathrm{~m}$ altitudinal scale in the AG region (Figure 6B,b), peaking at $3100 \mathrm{~m}$, the same as town scale. Altitude could even explain $77 \%$ of the variation in forest $C$ density at $100 \mathrm{~m}$ altitudinal scale (Figure $6 \mathrm{~b}$ ). Conversely to town scale, forest $\mathrm{C}$ density presented an inverted U-shape curve for altitude at sublot scale, which could explain $27 \%$ of the variation in forest $C$ density at plot scale (Figure $6 \mathrm{C}$ ), and up to $67 \%$ at $100 \mathrm{~m}$ altitudinal scale (Figure 6c).
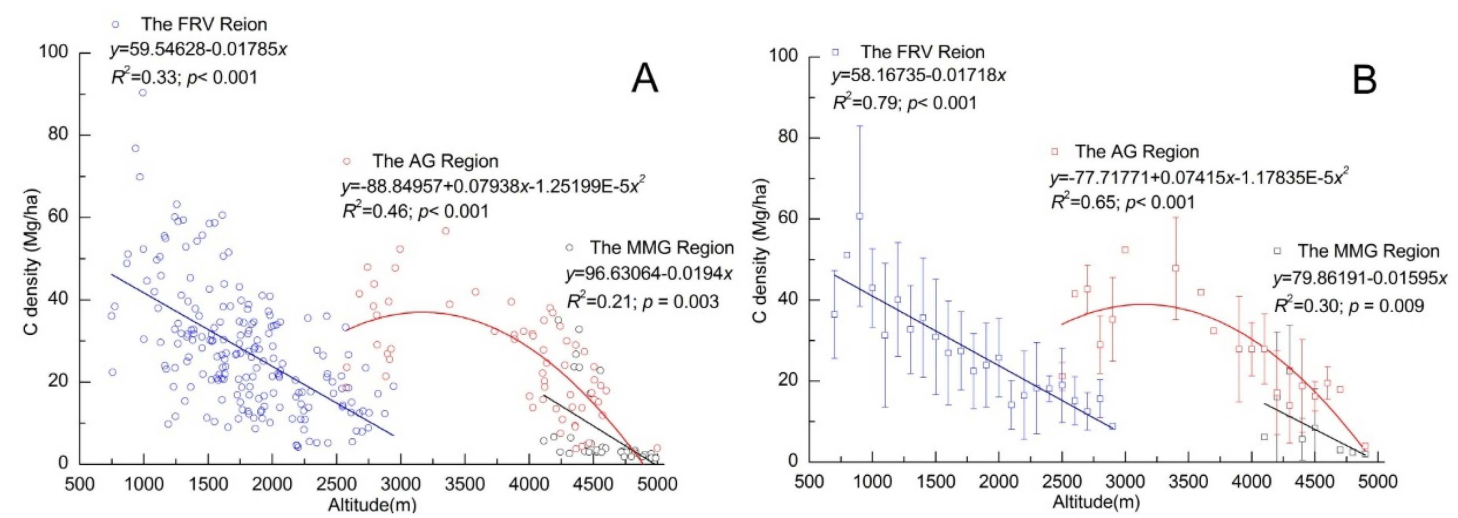

Figure 5. Altitudinal patterns of $C$ density of different geomorphological regions at town scale. Panel (A) was plot scale (one plot represents one town) and panel (B) was $100 \mathrm{~m}$ altitudinal scale. The blank, red and blue colors represent the FRV, AG and MMG regions, respectively.
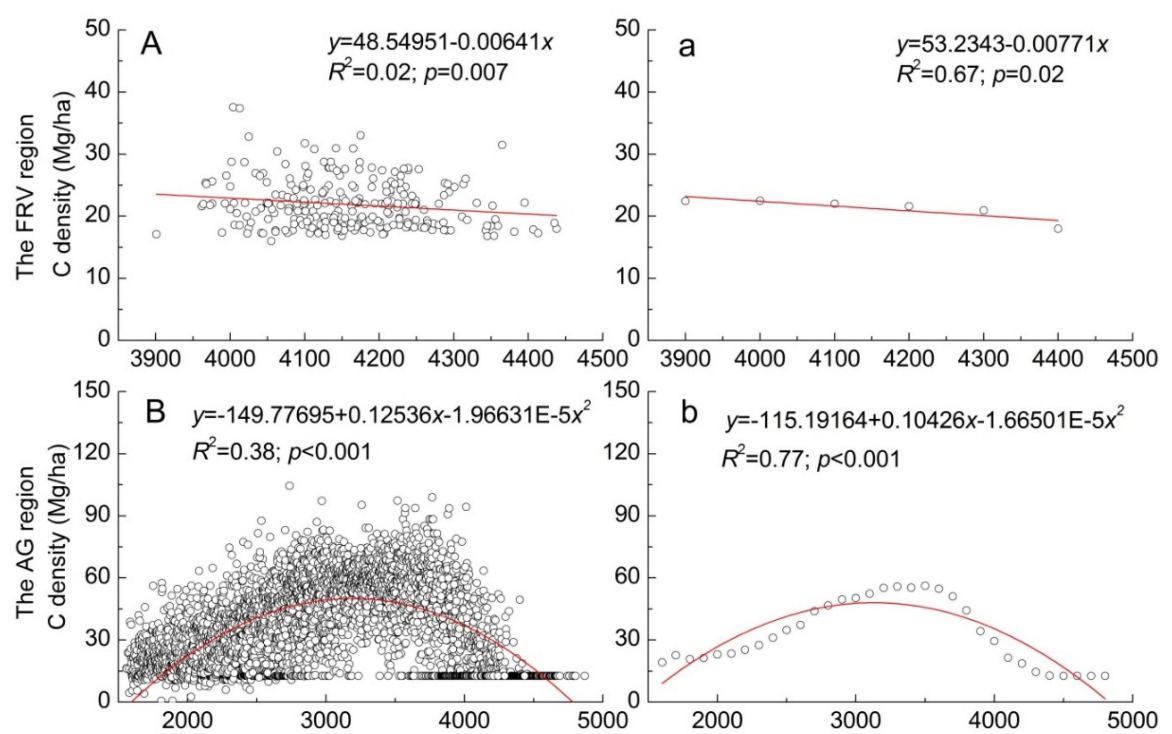

b $y=-115.19164+0.10426 x-1.66501 \mathrm{E}-5 x^{2}$ $R^{2}=0.77 ; p<0.001$
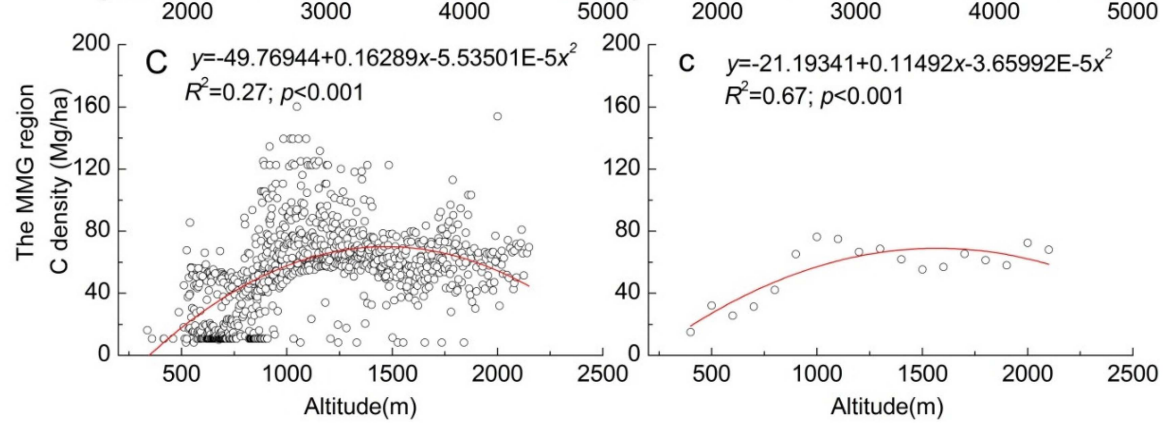

Figure 6. Altitudinal patterns of $\mathrm{C}$ density of different geomorphological regions at sublot scale. Panels with capital letters (A-C) were plot scale (one plot represents one sublot), and panels with small letters $(\mathbf{a}-\mathbf{c})$ were $100 \mathrm{~m}$ altitudinal scale. 


\section{Discussion}

\subsection{Error Analysis of the Accuracy of C Storage}

Due to the impact of the uplift of the Qinghai-Tibetan Plateau, terrain conditions were extremely complex in southwest, China, making it very difficult to estimate local vegetation $C$ storage accurately. It was necessary to evaluate the accuracy of the results.

At province scale, compared to vegetation C storage in Qinghai-Tibetan Plateau by Li et al. [41], the error was 11\% for towns in Qinghai Province (19.7 Tg vs. $17.53 \mathrm{Tg}$ ), and 1.5\% in the Tibet Autonomous Region (65.61 Tg vs. $64.53 \mathrm{Tg}$ ). No available study for comparison in Yunnan Province, while C storage was estimated based on the local Forest Resource Inventory database and model parameters, and the error was controlled within 5\% [19]. Overall, these results were highly comparable.

Among vegetation types, arbor forest $C$ storage was estimated based on the Forest Resource Inventory database, which was characterized by detailed classification for conifer trees, but not for broadleaf tree classification. The downstream area of the LRB, especially in Xishuangbanna Prefecture, where a large number of subtropical evergreen broadleaf forests were distributed, may arise in errors regarding $C$ storage accuracy. Based on the grass inventory database, aboveground $C$ storage of grassland was relatively accurate with an error of less than 10\% [26], but errors may arise regarding underground $\mathrm{C}$ storage, estimated using shoot/root ratios from published literature. Average $\mathrm{C}$ storage data were used in estimation in other vegetation types, and error may arise from the large difference between vegetation types and regions. However, the overall effects were limited, considering their small distributions.

\subsection{Influencing Mechanism for C Storage by Altitude}

Generally, vegetation $C$ storage increased with decreasing latitude [42]. However, in the southwest of China, especially in the Hengduan Mountains, the uplift of the Qinghai-Tibetan Plateau had changed the latitudinal distribution character of vegetation [43]. The terrain factor also affected spatial pattern of vegetation $C$ storage significantly, which exhibited nonlinear variation with latitudinal gradients (Figure 3). We stressed the influencing mechanism for $\mathrm{C}$ storage by altitude in three geomorphological types. In the FRV region, the vegetation $C$ density slightly decreased with increasing altitude, mostly less than $10 \mathrm{Mg} / \mathrm{ha}$. With a small variation range, forest C density mostly was about $20 \mathrm{Mg} / \mathrm{ha}$. In the AG region, the altitudinal range was obviously larger than the other two regions (Figure 4A). It had an inverse U-shape curve between $\mathrm{C}$ density and altitude both at town and sublot scale because a strong Foehn effect exists, which was caused by the specific terrain and resulted in the dry-hot valley [44]. Thus, the vegetation in middle altitude area was the richest and the $C$ density was high, while the $\mathrm{C}$ density was low in the high and low altitude areas. In the MMG region, the C density descended with the increasing altitude at town scale (Figure 5A), while there was a conic relationship between $\mathrm{C}$ density and altitude at sublot scale. The $\mathrm{C}$ density was highest at the altitude of $1000 \mathrm{~m}$. We found that $1000 \mathrm{~m}$ was the upper limit of rubber plantations. This was probably due to the destruction of natural vegetation and the substitution of plantation below $1000 \mathrm{~m}$.

Comprehensively, the altitude had the strongest impact on the vegetation $C$ density in the AG area, and changed the latitudinal pattern, resulted in higher C density in mid-altitude (3100 $\mathrm{m})$ than adjacent areas.

\subsection{Tradeoff between C Storage and Local Development}

There was enormous vegetation $C$ storage in the LRB, though it was severely disturbed due to economic development. In the upstream area, height, coverage and aboveground biomass of meadow communities were significant decreased with the increasing grazing intensity [45]. Also, in Xishuangbanna, driven by economic interests, seasonal rain forest had been replaced by rubber plantations and conserved only in the protected areas. C density in rubber plantations was 83.86-123.49 t/ha, which was lower than that of seasonal rain forest of 244.95-377.87 t/ha [46]. 
The area rubber plantation had reached 376,600 ha in 2014, three times in 1990 [47], resulting in huge $\mathrm{C}$ losses. Research indicated that deforestation, especially destruction of tropical rainforests, was the second-largest source of increased atmospheric $\mathrm{CO}_{2}$ concentration, following only fossil fuel combustion [48-50]. It suggested that tradeoff between local development and $C$ was an important issue faced by all governments. They should abandon the completely short-sighted focus on economic interests and take a holistic view to reserve the ecological land for ecological balance. For over-developed regions, it is necessary to appropriately adjust the industrial structure and guide economic behavior of local residents, so as to restore the ecological balance. The results of the study are help for understanding the spatial patterns and controlling mechanisms of local vegetation $C$ storage, which could be useful to balance $C$ storage and local development.

\section{Conclusions}

We estimated the vegetation $C$ storage of the LRB, and focused on the influence of altitude. As an important $C$ sink in China, the vegetation $C$ storage of the $\operatorname{LRB}(300.32 \mathrm{Tg}$ ) accounted for $4.68 \%-6.29 \%$ of the national total, with only $1.67 \%$ of the land area. And the majority of $C$ storage was contributed by forests, notably oaks, Abies and Picea. Further, different from the general pattern, the vegetation $C$ storage exhibited nonlinear variation with latitudinal gradients, which had two maximum value at $\mathrm{N} 21^{\circ}$ (Xishuangbanna) and N27 (Diqing). As the main influencing factors, altitude affected the distribution of local vegetation, and then changed the latitudinal patterns of vegetation $C$ storage, especially in the AG area. The C density in the mid-altitude $(3100 \mathrm{~m})$ of the AG area, which was dominated by dark coniferous forests, mainly Abies, Picea and alpine oak, was higher than that of adjacent areas.

The study provided insights into the spatial pattern of $C$ storage in complex terrain regions. Further study would integrate more influencing factors, including meteorological factors, other terrain factors and the human disturbance factor, to reveal deep controlling mechanisms for the spatial patterns of vegetation $C$ storage in complex terrain regions.

Acknowledgments: This research was funded by the National Natural Science Foundation of China (No. 41501607) and Beijing Municipal Natural Science Foundation (No. 8154046).

Author Contributions: Conceived and designed the paper: Long Chen, Gaodi Xie. Collected, analyzed data, wrote the paper: Changshun Zhang. Improved language: Chunlan Liu, Sha Pei. Partial data collection and processing: Qing Qiao. Partial data collection: Haihua Wang, Zheng, Li.

Conflicts of Interest: All authors have approved the content and there is no interest conflict among them.

\section{Appendix A}

Table A1. C storage and density at different administrative levels in the LRB.

\begin{tabular}{|c|c|c|c|c|c|c|c|c|}
\hline $\begin{array}{c}\text { Province/ } \\
\text { Autonomous } \\
\text { Region }\end{array}$ & $\begin{array}{l}\text { Prefecture/ } \\
\text { City/ } \\
\text { District }\end{array}$ & County & $\begin{array}{l}\text { Number } \\
\text { of } \\
\text { Towns }\end{array}$ & $\begin{array}{c}\text { Area } 10^{4} \\
\text { ha }\end{array}$ & $\begin{array}{c}\mathrm{C} \\
\text { Storage } \\
\mathrm{Tg}\end{array}$ & $\begin{array}{c}\text { C } \\
\text { Density } \\
\text { Mg/ha }\end{array}$ & $\begin{array}{c}\text { Area } \\
\text { Percentage } \\
\%\end{array}$ & $\begin{array}{c}\text { C Storage } \\
\text { Percentage } \\
\%\end{array}$ \\
\hline \multirow{4}{*}{ Qinghai } & \multirow{3}{*}{ Yushu } & Nangqian & 10 & 120.70 & 4.94 & 4.09 & 7.59 & 1.64 \\
\hline & & Yushu & 3 & 70.71 & 2.52 & 3.56 & 4.45 & 0.84 \\
\hline & & Zaduo & 8 & 356.55 & 12.25 & 3.43 & 22.42 & 4.08 \\
\hline & \multicolumn{2}{|c|}{ Subtotal } & 21 & 547.96 & 19.70 & 3.60 & 34.46 & 6.56 \\
\hline \multirow{10}{*}{ Tibet } & & Chaya & 13 & 79.79 & 10.61 & 13.30 & 5.02 & 3.53 \\
\hline & \multirow{6}{*}{ Changdu } & Changdu & 15 & 104.39 & 25.81 & 24.72 & 6.57 & 8.59 \\
\hline & & Dingqing & 8 & 30.86 & 0.51 & 1.65 & 1.94 & 0.17 \\
\hline & & Gongjue & 4 & 3.96 & 0.14 & 3.60 & 0.25 & 0.05 \\
\hline & & Jiangda & 5 & 32.85 & 1.61 & 4.91 & 2.07 & 0.54 \\
\hline & & Leiwuqi & 10 & 57.52 & 11.06 & 19.23 & 3.62 & 3.68 \\
\hline & & Mangkang & 11 & 47.61 & 11.71 & 24.60 & 2.99 & 3.90 \\
\hline & & Zuogong & 6 & 15.53 & 3.72 & 23.98 & 0.98 & 1.24 \\
\hline & Naqu & Baqing & 1 & 16.46 & 0.43 & 2.61 & 1.04 & 0.14 \\
\hline & \multicolumn{2}{|c|}{ Subtotal } & 73 & 388.97 & 65.61 & 16.87 & 24.46 & 21.85 \\
\hline
\end{tabular}


Table A1. Cont.

\begin{tabular}{|c|c|c|c|c|c|c|c|c|}
\hline $\begin{array}{c}\text { Province/ } \\
\text { Autonomous } \\
\text { Region }\end{array}$ & $\begin{array}{c}\text { Prefecture/ } \\
\text { City/ } \\
\text { District }\end{array}$ & County & $\begin{array}{c}\text { Number } \\
\text { of } \\
\text { Towns }\end{array}$ & $\begin{array}{c}\text { Area } 10^{4} \\
\text { ha }\end{array}$ & $\begin{array}{c}\mathrm{C} \\
\text { Storage } \\
\mathrm{Tg}\end{array}$ & $\begin{array}{c}\text { C } \\
\text { Density } \\
\text { Mg/ha }\end{array}$ & $\begin{array}{c}\text { Area } \\
\text { Percentage } \\
\%\end{array}$ & $\begin{array}{c}\text { C Storage } \\
\text { Percentage } \\
\%\end{array}$ \\
\hline \multirow{33}{*}{ Yunnan } & \multirow{2}{*}{ Baoshan } & Changning & 8 & 13.49 & 2.00 & 14.82 & 0.85 & 0.67 \\
\hline & & Longyang & 3 & 3.75 & 0.91 & 24.18 & 0.24 & 0.30 \\
\hline & \multirow{9}{*}{ Dali } & Dali & 11 & 7.64 & 0.81 & 10.64 & 0.48 & 0.27 \\
\hline & & Eryuan & 12 & 21.07 & 2.77 & 13.17 & 1.33 & 0.92 \\
\hline & & Heqing & 1 & 1.92 & 0.20 & 10.17 & 0.12 & 0.07 \\
\hline & & Jianchuan & 7 & 17.58 & 2.82 & 16.02 & 1.11 & 0.94 \\
\hline & & Nanjian & 6 & 9.04 & 1.04 & 11.45 & 0.57 & 0.34 \\
\hline & & Weishan & 8 & 21.30 & 2.70 & 12.65 & 1.34 & 0.90 \\
\hline & & Yangbi & 11 & 13.95 & 2.18 & 15.62 & 0.88 & 0.73 \\
\hline & & Yongping & 8 & 32.62 & 11.22 & 34.40 & 2.05 & 3.74 \\
\hline & & Yunlong & 10 & 36.22 & 7.41 & 20.46 & 2.28 & 2.47 \\
\hline & \multirow{2}{*}{ Diqing } & Deqin & 4 & 21.37 & 8.17 & 38.23 & 1.34 & 2.72 \\
\hline & & Weixi & 8 & 29.41 & 13.57 & 46.13 & 1.85 & 4.52 \\
\hline & \multirow{7}{*}{ Lincang } & Cangyuan & 7 & 10.11 & 3.59 & 35.52 & 0.64 & 1.20 \\
\hline & & Fengqing & 13 & 14.74 & 3.81 & 25.84 & 0.93 & 1.27 \\
\hline & & Gengma & 4 & 9.35 & 3.60 & 38.47 & 0.59 & 1.20 \\
\hline & & Linxiang & 5 & 6.16 & 2.01 & 32.64 & 0.39 & 0.67 \\
\hline & & Shuangjiang & 6 & 14.61 & 4.65 & 31.83 & 0.92 & 1.55 \\
\hline & & Yongde & 1 & 1.40 & 0.29 & 20.44 & 0.09 & 0.10 \\
\hline & & Yunxian & 11 & 18.87 & 4.84 & 25.62 & 1.19 & 1.61 \\
\hline & \multirow[t]{2}{*}{ Nujiang } & Lanping & 8 & 35.49 & 9.06 & 25.52 & 2.23 & 3.02 \\
\hline & & Jiangcheng & 1 & 7.26 & 0.85 & 11.69 & 0.46 & 0.28 \\
\hline & \multirow{7}{*}{ Pu'er } & Jingdong & 5 & 12.00 & 2.21 & 18.44 & 0.75 & 0.74 \\
\hline & & Jinggu & 11 & 52.59 & 16.76 & 31.87 & 3.31 & 5.58 \\
\hline & & Lancang & 19 & 51.73 & 18.87 & 36.49 & 3.25 & 6.28 \\
\hline & & Menglian & 4 & 4.89 & 0.91 & 18.58 & 0.31 & 0.30 \\
\hline & & Ning'er & 4 & 11.80 & 2.00 & 16.96 & 0.74 & 0.67 \\
\hline & & Simao & 4 & 16.97 & 6.57 & 38.72 & 1.07 & 2.19 \\
\hline & & Zhenyuan & 5 & 14.64 & 2.78 & 19.00 & 0.92 & 0.93 \\
\hline & \multirow{3}{*}{ Xishuangbanna } & Jinghong & 8 & 58.24 & 31.17 & 53.51 & 3.66 & 10.38 \\
\hline & & Menghai & 10 & 22.56 & 12.52 & 55.49 & 1.42 & 4.17 \\
\hline & & Mengla & 9 & 60.33 & 32.75 & 54.28 & 3.79 & 10.90 \\
\hline & \multicolumn{2}{|c|}{ Subtotal } & 232 & 653.11 & 215.01 & 32.92 & 41.08 & 71.59 \\
\hline \multicolumn{3}{|c|}{ Total } & 326 & 1590.04 & 300.32 & 18.89 & 100.00 & 100.00 \\
\hline
\end{tabular}

\section{References}

1. Piao, S.L.; Fang, J.; Huang, Y. The carbon balance of terrestrial ecosystems in China. China Basic Sci. 2010, 12, 20-22. [CrossRef] [PubMed]

2. Dixon, R.K.; Solomon, A.M.; Brown, S.; Houghton, R.A.; Trexier, M.C.; Wisniewski, J. Carbon pools and flux of global forest ecosystem. Science 1994, 263, 185-190. [CrossRef] [PubMed]

3. Scurlock, J.M.O.; Cramer, W.; Olson, R.J.; Parton, W.J.; Prince, S.D. Terrestrial NPP: Towards a consistent data set for global model evaluation. Ecol. Appl. 1999, 9, 913-919. [CrossRef]

4. $\mathrm{Hu}, \mathrm{H}$.; Wang, G. Changes in forest biomass carbon storage in the South Carolina Piedmont between 1936 and 2005. Forest Ecol. Manag. 2008, 255, 1400-1408. [CrossRef]

5. Pan, Y.D.; Birdsey, R.A.; Fang, J.; Houghton, R.; Kauppi, P.E.; Kurz, W.A.; Phillips, O.L.; Shvidenko, A.; Lewis, S.L.; Canadell, J.G.; et al. A large and persistent carbon sink in the world's forests. Science 2011, 333, 988-993. [CrossRef] [PubMed]

6. Guo, Z.D.; Hu, H.; Li, P.; Li, N.; Fang, J. Spatio-temporal changes in biomass carbon sinks in China's forests during 1977-2008. Sci. China Life Sci. 2013, 56, 661-671. [CrossRef] [PubMed]

7. Hu, H.F.; Wang, S.; Guo, Z.; Xu, B.; Fang, J. The stage-classified matrix models project a significant increase in biomass carbon stocks in China's forests between 2005 and 2050. Sci. Rep. 2015, 5, 11203. [CrossRef] [PubMed]

8. Fang, J.Y.; Huang, Y.; Zhu, J.; Sun, W.; Hu, H. Carbon budget of forest ecosystems and its driving forces. China Basic Sci. 2015, 3, 20-25.

9. Zha, T.G.; Zhang, Z.; Zhu, J.; Cui, L.; Zhang, J.; Chen, J.; Tan, J.; Fang, X. Carbon storage and carbon cycle in forest ecosystem. Sci. Soil Water Conserv. 2008, 6, 112-119. 
10. Song, C.; Woodcock, C.E. A regional forest ecosystem carbon budget model: Impacts of forest age structure and landuse history. Ecol. Model. 2003, 164, 33-47. [CrossRef]

11. Nave, L.E.; Vance, E.D.; Swanston, C.W.; Curtis, P.S. Harvest impacts on soil carbon storage in temperate forests. For. Ecol. Manag. 2010, 259, 857-866. [CrossRef]

12. Stegen, J.C.; Swenson, N.G.; Enquist, B.J.; White, E.P.; Phillips, O.L.; Jørgensen, P.M.; Weiser, M.D.; Mendoza, A.M.; Vargas, P.N. Variation in above-ground forest biomass across broad climatic gradients. Glob. Ecol. Biogeogr. 2011, 20, 744-754. [CrossRef]

13. Liu, Y.; Sun, X.; Fan, J.; Zhang, J. Carbon storage and its dynamics of forest vegetations in Liaoning Province. Ecol. Environ. Sci. 2015, 24, 211-216.

14. Huang, L.; Shao, Q.; Liu, J. The spatial and temporal patterns of carbon sequestration by forestation in Jiangxi Provinc. Acta Ecol. Sin. 2015, 35, 2105-2118.

15. De Castilho, C.V.; Magnusson, W.E.; de Araújo RN, O.; Luizao, R.C.; Luizao, F.J.; Lima, A.P.; Higuchi, N. Variation in aboveground tree live biomass in a central Amazonian Forest: Effects of soil and topography. For. Ecol. Manag. 2006, 234, 85-96. [CrossRef]

16. Xiao, Y.; An, K.; Yang, Y.; Xie, G.; Lu, C. Forest carbon storage trends along altitudinal gradients in Beijing, China. J. Resour. Ecol. 2014, 5, 148-156.

17. Djukic, I.; Zehetner, F.; Tatzber, M.; Gerzabek, M.H. Soil organic-matter stocks and characteristics along an Alpine elevation gradient. J. Plant Nutr. Soil Sci. 2010, 173, 30-38. [CrossRef]

18. Takeuchi, T.; Kobayashi, T.; Nashimoto, M. Altitudinal differences in bark stripping by sika deer in the subalpine coniferous forest of Mt. Fuji. Forest Ecol. Manag. 2011, 261, 2089-2095. [CrossRef]

19. Fang, J.Y.; Chen, A. Dynamic forest biomass carbon pools in China and their significance. Acta Bot. Sin. 2001, 43, 967-973.

20. He, D.M.; Tang, Q. China International Rivers; Science Press: Beijing, China, 2000; pp. 1-209.

21. He, D.M.; Feng, Y.; Hu, J. Utilization of Water Resources and Environmental Conservation in the International Rivers, Southwest China; Science Press: Beijing, China, 2007; pp. 1-225.

22. Wang, J.; Cui, B.; Yao, H. Spatio-temporal dynamic study on landscape patterns in Lancang River watershed of Yunnan province. J. Soil Water Conserv. 2007, 21, 85-97.

23. Qiu, G.X. Research on Environmental Planning of Lancang River Basin in Yunnan Province; Yunnan Environmental Science Press: Kunming, China, 1996; pp. 1-10.

24. Luo, T.X. Patterns of Net Primary Productivity for Chinese Major Forest Types and Their Mathematical Models. Ph.D. Thesis, The Commission for Integrated Survey of Natural Resources, Chinese Academy of Sciences, Beijing, China, 1996.

25. Fu, H.; Chen, A. Accumulation of above-ground biomass and nutrients in swidden fallows: A comparison between planted alder fallows and unmanaged grassy fallows in Yunnan. Acta Ecol. Sin. 2004, 24, 209-214.

26. Department of Animal Product of Ministry of Agriculture of China. China Grassland Resource Data; China Agriculture Scientech Press: Beijing, China, 1994; pp. 1-366.

27. Crutzen, P.J.; Andreae, M.O. Biomass burning in the tropics: Impact on the atmospheric chemistry and biogeochemical cycles. Science 1990, 250, 1669-1678. [CrossRef] [PubMed]

28. Fang, J.Y.; Chen, A.; Peng, C.; Zhao, S.; Ci, L. Changes in forest biomass carbon storage in China between 1949 and 1998. Science 2001, 292, 2320-2322. [CrossRef] [PubMed]

29. Fang, J.Y.; Guo, Z.; Piao, S.; Chen, A. Terrestrial vegetation carbon sinks in China, 1981-2000. Sci. China Earth Sci. 2007, 37, 804-812. [CrossRef]

30. Liu, Y.C.; Yu, G.; Wang, Q.; Zhang, Y.; Xu, Z. Carbon carry capacity and carbon sequestration potential in China based on an integrated analysis of mature forest biomass. Sci. China Life Sci. 2014, 57, 1218-1229. [CrossRef] [PubMed]

31. Yang, F.; Huang, L.; Shao, Q.; Bao, Y. Forest carbon storage and its sequestration potential in the southeast of Guizhou Province during 1990-2050. J. Geo-Inf. Sci. 2015, 17, 309-316.

32. Fang, J.Y.; Chen, A.; Zhao, S.; Ci, L. Estimating biomass carbon of China's forests: Supplementary notes on report published in science (291:2320-2322) by Fang et al. (2001). Acta Phytoecol. Sin. 2002, 26, 243-249.

33. Fang, J.Y.; Liu, G.; Xu, S. Carbon cycling in terrestrial ecosystems in China, In Studies on Emissions and Their Mechanisms of Greenhouse Gases in China; Wang, G.C., Wen, Y., Eds.; China Environmental Science Press: Beijing, China, 1996; pp. 81-149. 
34. Tang, J.W.; Pang, J.; Chen, M.; Guo, X.; Zeng, R. Biomass and its estimation model of rubber plantations in Xishuangbanna, Southwest China. Chin. J. Ecol. 2009, 28, 1942-1948.

35. You, X.Q. Requirement on Nutrient and Accumulation on Biomass by up-Ground Parts of Tea Plants under Field Conditions. Master's Thesis, Tea Research Institute, Chinese Academy of Agricultural Sciences, Hangzhou, China, 2008.

36. Nie, D.P. Structural dynamics of bamboo forest stands. Sci. Silv. Sin. 1994, 30, 201-208.

37. Piao, S.L.; Fang, J.; He, J.; Xiao, Y. Spatial Distribution of Grassland Biomass in China. Acta Phytoecol. Sin. 2004, 28, 491-498.

38. Pacala, S.W.; Hurtt, G.C.; Baker, D.; Peylin, P.; Houghton, R.A.; Birdsey, R.A.; Heath, L.; Sundquist, E.T.; Stallard, R.F.; Ciais, P.; et al. Consistent land- and atmosphere-based US carbon sink estimates. Science 2001, 292, 2316-2320. [CrossRef] [PubMed]

39. Wang, X.K.; Feng, Z.; Ouyang, Z. Vegetation carbon storage and density of forest ecosystems in China. Chinese J. Appl. Ecol. 2001, 12, 13-16.

40. Yen, T.; Wang, C. Assessing carbon storage and carbon sequestration for natural forests, man-made forests, and bamboo forests in Taiwan. Int. J. Sustain. Dev. World 2013, 20, 455-460. [CrossRef]

41. Li, W.H.; Zhou, X. Ecosystems of Tibetan Plateau and Approach for Their Sustainable Management; Guangdong Science \& Technology Press: Guangzhou, China, 1998; pp. 1-382.

42. Ding, W.; He, N. Forest carbon storage along the north-south transect of eastern China: Spatial patterns, allocation, and influencing factors. Ecol. Indic. 2016, 61, 960-967.

43. Jiang, Z. Zonality of distribution of physico-georaphical zone in China. Sci. Geogr. Sin. 1990, 10, 114-124.

44. Ming, Q.; Shi, Z. New discussion on dry valley formation in the Three Parallel Rivers Region. J. Desert Res. 2007, 27, 99-104.

45. Ren, Q.; Cui, X.; Zhao, B. Effects of grazing impact on community structure and productivity in an alpine meadow. Acta Pratac. Sin. 2008, 17, 134-140.

46. Song, Q.H.; Zhang, Y. Biomass, carbon sequestration and its potential of rubber plantations in Xishuangbanna, Southwest China. Chin. J. Ecol. 2010, 29, 1887-1891.

47. Liao, C.; Li, P.; Feng, Z.; Zhang, J. Area monitoring by remote sensing and spatiotemporal variation of rubber plantations in Xishuangbanna. Trans. CSAE 2014, 30, 170-180.

48. Detwiler, R.P.; Hall, C.S. Tropical forests and the global carbon cycle. Science 1988, 239, 42-47. [CrossRef] [PubMed]

49. Houghton, R.A. Land-use change and the carbon cycle. Glob. Chang. Biol. 1995, 1, 275-287. [CrossRef]

50. Geng, Y.B.; Dong, Y.; Meng, W. Progresses of terrestrial carbon cycle studies. Prog. Geogr. 2000, 19, $297-306$. 